\title{
Trace metal accumulation in marine macrophytes: Hotspots of coastal contamination worldwide
}

\author{
David Sánchez-Quiles ${ }^{1}$, Núria Marbà ${ }^{1}$, Antonio Tovar-Sánchez ${ }^{1,2}$ \\ ${ }^{1}$ Department of Global Change Research. Mediterranean Institute for Advanced Studies, IMEDEA (CSIC-UIB), Miguel \\ Marqués 21, 07190 Esporles, Balearic Island, Spain. \\ ${ }^{2}$ Department of Ecology and Coastal Management. Andalusian Institute for Marine Science, ICMAN (CSIC). Campus \\ Universitario Río San Pedro, 11510 Puerto Real, Cádiz. Spain.
}

\begin{abstract}
This study compiles, from 155 peer review research articles, almost 23,000 estimates of trace metals (As, Cd, Co, $\mathrm{Cr}, \mathrm{Cu}, \mathrm{Fe}, \mathrm{Hg}, \mathrm{Mn}, \mathrm{Ni}, \mathrm{Pb}$ and $\mathrm{Zn}$ ) contents in natural populations of marine macrophytes (seagrasses, chlorophytae, phaeophytae and rhodophytae) worldwide. The objective was to explore the distribution of these metals, to examine its trends of accumulation and to identify hotspots of coastal pollution. Our results point out phaeophytae as the group with the maximum accumulation capacity and tolerance to elevated concentrations of metals, and indicate that, despite of the geographic differences and local and regional influences, exist a similar atomic ratio of trace metals accumulation in the four groups of marine macrophytes regardless the species. The mapping of geographic distribution of metal accumulation in marine macrophytes identifies some coastal areas as hotspots of trace metal contamination. This work aims to provide a reference for futures studies.
\end{abstract}

\section{INTRODUCTION}

Studies of trace metals concentrations in marine macrophytes are essential to elucidate their role in the ecology and oceans. While global assessments of concentrations and requirements of metals in marine organisms have been examined for phytoplankton and for seagrass leaves [1,2], information about the most representative macrophytes is almost nonexistent.

In marine macrophytes $\mathrm{Co}, \mathrm{Cu}, \mathrm{Fe}, \mathrm{Mn}, \mathrm{Ni}$ and $\mathrm{Zn}$ act as micronutrients working as cofactors in several enzymes and vitamins, and in several metabolic paths $[3,4]$. However, $\mathrm{As}, \mathrm{Cd}, \mathrm{Cr}, \mathrm{Hg}$ or $\mathrm{Pb}$ do not have a essential biological role in plant's metabolism and even in low concentrations have negative effects on plant growth [5-7]. Since metal accumulation in marine macrophytes depends strongly on the specie, location, and season [8], a global overview of metal composition might help to better understanding of biological requirements and tolerance under different environments conditions.

Here, we have assessed the variability in accumulation of major trace metals in seagrasses and in the three groups of macroalgae (phaeophytae, chlorophytae and rhodophytae) and we have identified some hotspots of coastal contamination by compiling reported estimates of trace metal concentrations in marine macrophytes worldwide. Results from this meta-analysis will be useful to compare future results from studies on metal composition in macrophytes and to have a baseline that allows assess and detect natural or anthropogenic environmental changes.

\section{MATERIALS AND METHODS}

The data set includes concentration of eleven trace metals (As, $\mathrm{Cd}, \mathrm{Co}, \mathrm{Cr}, \mathrm{Cu}, \mathrm{Fe}, \mathrm{Hg}, \mathrm{Mn}, \mathrm{Ni}, \mathrm{Pb}$ and $\mathrm{Zn}$ ) in marine macrophytes worldwide. From each study we recovered latitude and longitude, macrophyte species, macrophyte group, concentration of each metal and year of publication. Due to the great number of observations collected we have used robust statistics estimators to characterize the populations: the 0.2-truncated mean, used as robust measure of the central tendency, and the 0.2-Winsorized Standard Deviation, used as a robust estimation of the variability. As the robust, the resampling methods provide consistent results. These are based on repeated sampling within the same sample. Here we used one of the most implemented resampling techniques: the bootstrap, in order to constructing hypothesis tests through the estimation of intervals to compare differences between two independent populations. For each analysis we performed 1,000 resamples of each sample.

\section{RESULTS AND DISCUSSION}

The data set includes values of trace metal concentrations in marine macrophytes reported in 155 peer review papers published between 1956 and 2014. We compiled a total of 22,969 estimates of concentration for different metals: As (2.4\%), Cd (13.5\%), Co (4.6\%), Cr (6.1\%), Cu (14.0\%), $\mathrm{Fe}(10.1 \%), \mathrm{Hg}(4.3 \%), \mathrm{Mn}(9.2 \%), \mathrm{Ni}(8.5 \%), \mathrm{Pb}(12.4$ $\%)$ and $\mathrm{Zn}(14.7 \%)$ in seagrasses (34.9\%), chlorophytae 
(25.9\%), phaeophytae (22.5\%) and rhodophytae (16.7\%) with a widely geographical distribution.

Our results reveals the different capacity of the marine macrophytes to accumulate metals in their tissues with a significance level of 0.05 : We have found that 1) phaeophytae present significantly higher concentrations than seagrasses, chlorophytae and rhodophytae of As, Cd, $\mathrm{Co}$ and $\mathrm{Zn}$; 2) Chlorophytae shows the highest concentrations of $\mathrm{Fe}$ and $\mathrm{Mn}$; 3) Seagrasses present the highest concentration of $\mathrm{Cu}$ and the lowest of $\mathrm{Hg}$ and $\mathrm{Mn}$; and 4) Rhodophytae have significantly lower concentrations in 5 of the 11 trace metals studied, than the other plants: i.e. $\mathrm{Cr}, \mathrm{Cu}, \mathrm{Fe}, \mathrm{Pb}$ and $\mathrm{Zn}$. Moreover, the atomic ratio of metals concentrations in each group show similar pattern of accumulation suggesting that the ability to accumulate trace metal is equal in all macrophytes, regardless the different species and locations.

Due to marine macrophytes are good tools to control metal concentrations, we have identified some hotspots of trace metals in coastal areas worldwide (Fig. 1). Some of these areas are clearly influenced by human activities that increase the amount of metals discharged in the marine ecosystem. That is the case of the coasts of the Mediterranean and the Black Sea, where we have found many hotspots of trace metals pollutions (i.e. $\mathrm{Cd}, \mathrm{Cr}, \mathrm{Cu}$, $\mathrm{Fe}, \mathrm{Hg}, \mathrm{Ni}, \mathrm{Pb}$ and $\mathrm{Zn}$ ). The gulfs region of South Australia (Spencer Gulf and Gulf St Vicent) is another example of metal contamination by anthropogenic activities. We have found in this region, elevated concentrations of $\mathrm{As}, \mathrm{Cd}, \mathrm{Pb}$ and $\mathrm{Zn}$.

The Bay of Bengal, in the Indian Sea, is another hotspot of trace metal contamination due to the elevated concentration of metals found in marine macrophytes. Concretely, in the coasts of Andaman Island we have found elevated concentrations of $\mathrm{Cr}, \mathrm{Cu}$ and $\mathrm{Mn}$.

The particular geography of Chile and the upwelling that occurs in its coast could increase the concentrations of trace metals in marine macrophytes. We have found along the coast of Chile hotspots of $\mathrm{Cr}, \mathrm{Cu}, \mathrm{Fe}, \mathrm{Ni}$ and $\mathrm{Zn}$.

It is remarkable that, although the Antarctic is far from human influence, its coast presents elevated concentrations of As, and Co in plants collected from King George Island. This could be due to natural processes like the volcanic composition of the rocks near the sampling place. This natural origin of As contrast with other hotspots found in other bays from England, France and China. It is also notable that the Gulf of Mexico does not present any hotspot instead of its strong anthropogenic pressure.

The extensive database of metal concentration in marine macrophytes compiled in the present work could help in future monitory programs of the coastal pollution and provide a reference for futures studies.

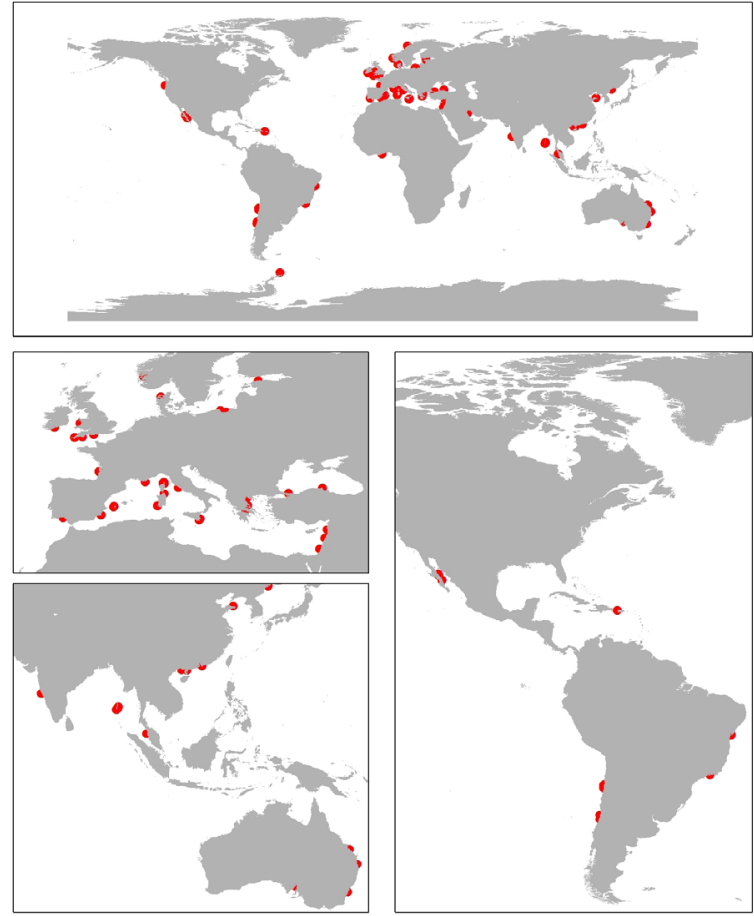

Fig. 1. Worldwide hotspots of trace metals.

\section{REFERENCES}

1. Govers LL, Lamers LPM, Bouma TJ, Eygensteyn J, de Brouwer JHF, Hendriks AJ, Huijbers CM, van Katwijk MM. Seagrasses as indicators for coastal trace metal pollution: A global meta-analysis serving as a benchmark, and a Caribbean case study. Environ. Pollut. 2014 Dec;195:210-217.

2. Twining BS, Baines SB. The trace metal composition of marine phytoplankton. Annu. Rev. Mar. Sci. 2013;5:191215.

3. Fageria NK, Baligar VC, Clark RB. Micronutrients in Crop Production. In: Donald L. Sparks, editor. Adv. Agron. [Internet]. Academic Press; 2002 [cited 2014 Feb 25]. p. 185-268.

4. Marschner H. 9 - Functions of Mineral Nutrients: Micronutrients. In: Marschner H, editor. Miner. Nutr. High. Plants Second Ed. [Internet]. London: Academic Press; 1995 [cited 2014 Apr 26]. p. 313-404.

5. Lamai C, Kruatrachue M, Pokethitiyook P, Upatham ES, Soonthornsarathool V. Toxicity and Accumulation of Lead and Cadmium in the Filamentous Green Alga Cladophora fracta (O.F. Muller ex Vahl) Kutzing: A Laboratory Study. ScienceAsia. 2005;31:121-127.

6. Stewart JG. Effects of lead on the growth of four species of red algae. Phycologia. 1977 Mar;16:31-36.

7. Strömgren T. The effect of lead, cadmium, and mercury on the increase in length of five intertidal fucales. J. Exp. Mar. Biol. Ecol. 1980;43:107-119.

8. Hou X, Yan X. Study on the concentration and seasonal variation of inorganic elements in 35 species of marine algae. Sci. Total Environ. 1998 Oct;222:141-156. 